\title{
A Review of the Role of Carcinoembryonic Antigen in Clinical Practice
}

\author{
Claire Hall $^{1}$, Louise Clarke ${ }^{1}$, Atanu Pal ${ }^{1,2}$, Pamela Buchwald ${ }^{1}$, Tim Eglinton ${ }^{1}$, Chris Wakeman ${ }^{1}$, Frank Frizelle \\ ${ }^{1}$ Colorectal Unit, Department of Surgery, University of Otago, Christchurch, New Zealand; ${ }^{2}$ Norfolk \& Norwich University Hospital, Norwich, \\ $\mathrm{UK}$
}

Carcinoembryonic antigen (CEA) is not normally produced in significant quantities after birth but is elevated in colorectal cancer. The aim of this review was to define the current role of CEA and how best to investigate patients with elevated CEA levels. A systematic review of CEA was performed, in accordance with the Preferred Reporting Items for Systematic Reviews and Meta-Analyses guidelines. Studies were identified from PubMed, Cochrane library, and controlled trials registers. We identified 2,712 papers of which 34 were relevant. Analysis of these papers found higher preoperative CEA levels were associated with advanced or metastatic disease and thus poorer prognosis. Postoperatively, failure of CEA to return to normal was found to be indicative of residual or recurrent disease. However, measurement of CEA levels alone was not sufficient to improve survival rates. Two algorithms are proposed to guide investigation of patients with elevated CEA: one for patients with elevated CEA after CRC resection, and another for patients with de novo elevated CEA. CEA measurement has an important role in the investigation, management and follow-up of patients with colorectal cancer.

Keywords: Carcinoembryonic antigen; Colorectal cancer; Recurrence

\section{INTRODUCTION}

Carcinoembryonic antigen (CEA) was first isolated from human colorectal cancer (CRC) tissue in 1965 by Gold and Freedman [1, 2 ]. It is a foetal glycoprotein and is not usually produced in significant quantity after birth. CEA can become elevated in a number of pathologies. The most common clinical use is surveillance for recurrence of CRC. CEA levels are also sometimes measured in patients without a history of CRC. Elevated CEA in both situations presents a management dilemma to the colorectal surgeon, particularly in deciding the appropriate tests and the subsequent follow-up if those tests are inconclusive, and this led us to conduct this review. This review aims to evaluate the role of CEA in clini-

Received: July 29, 2019 - Accepted: November 13, 2019

Correspondence to: Atanu Pal, M.A. M.D. FRCS.

General Surgery Department, Norfolk and Norwich University Hospital NHS

Foundation Trust, Colney Lane, Norwich NR4 7UY, UK

Tel: +44-1603-286286, Email: atanu.pal@doctors.org.uk

ORCID code: https://orcid.org/0000-0002-2144-6824

(C) 2019 The Korean Society of Coloproctology

This is an open-access article distributed under the terms of the Creative Commons Attribution NonCommercial License (http://creativecommons.org/licenses/by-nc/4.0) which permits unrestricted noncommercial use, distribution, and reproduction in any medium, provided the original work is properly cited. cal colorectal practice, including the prognostic significance of CEA in patients with CRC, the role of CEA in follow-up after $\mathrm{CRC}$ resection, and the management of patients with raised CEA and no history of CRC.

\section{METHODS}

A systematic search was performed in accordance with the PRISMA (Preferred Reporting Items for Systematic Reviews and Meta-Analyses) guidelines. The MeSH headings "Carcinoembryonic antigen," "CEA," and "Colorectal Neoplasm" were used to identify relevant studies in the PubMed and Cochrane Library Databases.

Studies included had to be published in English from January 1, 1990, to April 30, 2017, be full text articles, and have comparison groups in which the CEA level was used to determine a component of management or outcome. Data were extracted from the included articles by 2 authors according to the aims of our review: prognostic significance of CEA in patients with CRC, role of CEA in follow-up after CRC resection, and management of patients with raised CEA and no history of CRC. Results were described qualitatively. No statistical analyses were performed. 


\section{RESULTS}

Of the 2,712 papers identified, 271 were screened in abstract form by 2 authors independently. Thirty-two were deemed relevant, after which the full texts of the articles were obtained and reviewed by 2 authors (Fig. 1). A hand search of the reference lists found no additional studies.

\section{Preoperative CEA and prognosis}

Most trials were retrospective (Table 1). Elevated preoperative CEA predicted overall survival across stage I to stage III CRC, with elevated preoperative CEA carrying a $62 \%$ increase in the danger of death compared with a normal CEA level [3]. The 5 -year disease-free survival was $84.6 \%$ vs. $69.8 \%$ [4], and the 5 -year overall survival was $74.5 \%$ vs. $63.4 \%$ [5]. However, a study of 2 cohorts with Duke C cancer, 1990-2000 and 2001-2004, found that the predictive value of preoperative CEA was lost in the more recent cohort [6], and may be due to improved chemotherapy regimens. Higher preoperative CEA levels were associated with advanced disease stage.

\section{Postoperative CEA and prognosis}

Kim et al. [7] hypothesized that after curative surgery, and therefore after resection of the source of CEA, CEA levels would decrease exponentially. CEA was measured preoperatively and at day 7 and day 30 postoperatively. In the patient group where the CEA level had decreased exponentially, survival was significantly

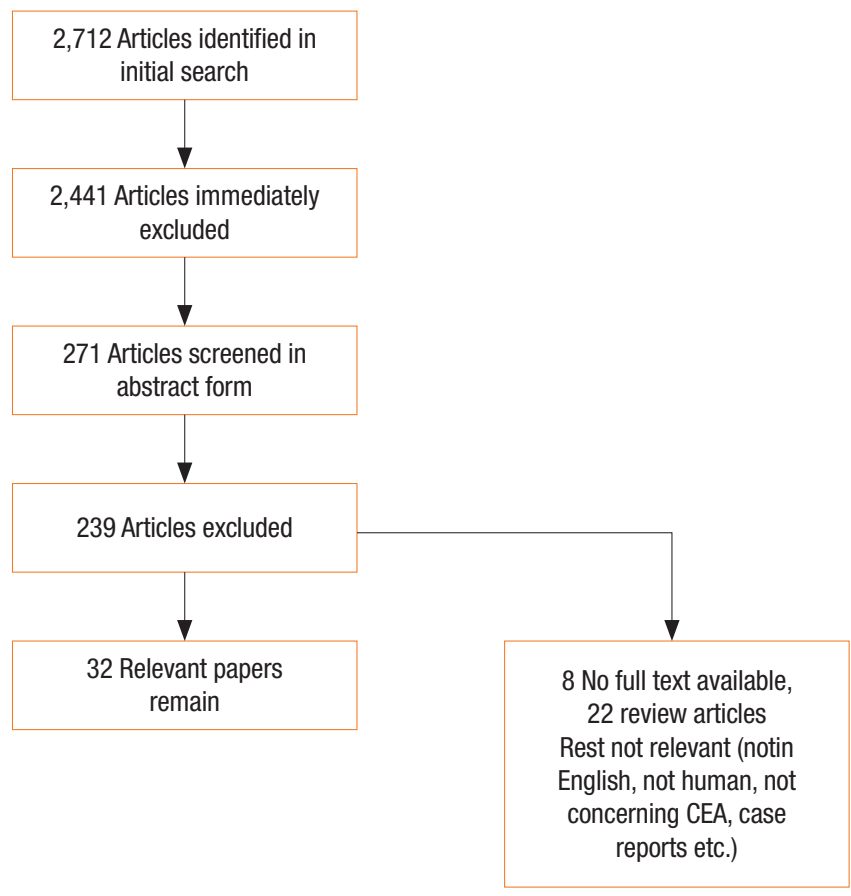

Fig. 1. Identification, screening, and selection of papers for inclusion. CEA, carcinoembryonic antigen. greater than it was in the group where CEA remained elevated, with a trend to increased disease-free survival. Similarly, in patients with stage $4 \mathrm{CRC}$ who underwent a R0 resection, elevated postoperative CEA and CA 19-9 were associated with reduced disease-free survival [8]. Failure of the CEA to return to normal after surgery was indicative of residual or recurrent disease, with CEAs over $10 \mathrm{ng} / \mathrm{mL}$ being strongly associated with metastatic disease.

\section{Preoperative CEA and response to neoadjuvant treatment}

In rectal cancer, elevated pretreatment CEA levels are associated with a poor response to neoadjuvant treatment, with a retrospective analysis of patients with stage I-III rectal cancer showing significantly decreased pathological complete response, pathological tumor regression, tumor downstaging, and overall survival [9].

\section{CEA in follow-up after CRC resection}

Two recent meta-analyses have shown no survival benefit with increased surveillance after resection for CRC $[10,11]$. For CEA specifically, we identified 8 randomized controlled trials (RCT, Table 2). In a RCT looking at managing a rising CEA with a second-look laparotomy compared to conservative treatment [12], no survival advantage was noted, and the study was terminated. CEA began increasing 323 days prior to the onset of clinically evident recurrent disease. A subgroup analysis was not performed, so whether the R0 resection of recurrent or metastatic disease had improved disease-specific survival compared to those with unresectable disease was not clear. The results were also difficult to interpret in the modern setting, as today, a 'second look' laparotomy would only be performed on patients with proven resectable disease, and this selected group would be expected to have an improved survival if compared to patients with widespread disease.

More recent trials [13-21] compared a standard follow-up regimen to a higher intensity follow-up, though the regimens were heterogeneous (Table 3). In the FACs (Follow-up After Colorectal Surgery) trial [15], more intensive follow-up with CEA and computed tomography (CT) scanning increased the rate of surgical treatment for recurrent disease, but without survival advantage. The accuracy of a single CEA measurement was poor, with the conclusion that the CEA trend, rather than stand-alone measurements, should be used [22].

The Dutch trial 'CEAwatch' investigated the effect of the intensity of the CEA measurement on the detection of recurrent disease and the proportion of curable recurrences [16]. Here, an elevated CEA would trigger repeat CEA testing and, if maintained, chest/abdomen CT. Intensive surveillance ( 8 weekly CEA) detected more patients with recurrence who had undergone a curative treatment, defined as an R0 resection, compared to the control group (3 monthly CEA: 35\% vs. 22\%) [16]. No improvement in overall or disease-free survival was found. The only survival benefit was when recurrences were detected by using CEA or imaging as compared to those detected by using patients' self-re- 


\section{Coloproctology cair eal, etal}

Table 1. CEA and prognosis: selected studies

\begin{tabular}{|c|c|c|c|c|c|c|c|c|c|}
\hline Author & Year & Origin & Study type & Study summary & Endpoint & $\begin{array}{c}\text { No. of } \\
\text { patients }\end{array}$ & Age $(\mathrm{yr})^{\mathrm{a}}$ & $\begin{array}{l}\text { Sex ratio } \\
\text { (\%male) }\end{array}$ & Outcome summary \\
\hline Stelzner [68] & 2005 & Germany & $\begin{array}{l}\text { Cohort } \\
\text { (retrospective } \\
\text { database) }\end{array}$ & $\begin{array}{l}\text { Database review } \\
\text { for predictors of } \\
\text { survival in } \\
\text { colorectal cancer }\end{array}$ & $\begin{array}{l}\text { Overall survival } \\
\text { in stage IV } \\
\text { colorectal } \\
\text { cancer }\end{array}$ & 186 & $\begin{array}{l}68.6 \text { (range, } \\
\text { 30-92) }\end{array}$ & 54.3 & $\begin{array}{l}\text { Preop CEA } \geq 5 \mathrm{ng} / \mathrm{mL} \\
\text { associated with decreased } \\
\text { overall survival in stage IV } \\
\text { disease. }\end{array}$ \\
\hline Katoh [6] & 2008 & Japan & $\begin{array}{l}\text { Cohort } \\
\text { (retrospective } \\
\text { database) }\end{array}$ & $\begin{array}{l}\text { Review of preop } \\
\text { CEA levels in } \\
\text { Dukes C } \\
\text { patients }\end{array}$ & Survival & $\begin{array}{l}\text { Retrospective: } \\
237 \text {; } \\
\text { prospective: } \\
197\end{array}$ & $\begin{array}{l}54.4 \% \geq 60 \text { in } \\
\text { retrospective; } \\
63.5 \% \geq 60 \\
\text { in prospective }\end{array}$ & $\begin{array}{l}\text { Retrospective: } \\
59.1 \\
\text { prospective: } \\
57.4\end{array}$ & $\begin{array}{l}\text { CEA } \leq 2.5 \mathrm{ng} / \mathrm{mL} \text { was a } \\
\text { predictor of disease-free } \\
\text { survival in Dukes C in } \\
\text { earlier cohort. Association } \\
\text { lost in later cohort, } \\
\text { possibly due to improved } \\
\text { chemotherapy. }\end{array}$ \\
\hline Kim [7] & 2009 & Korea & $\begin{array}{l}\text { Cohort } \\
\text { (retrospective } \\
\text { data base) }\end{array}$ & $\begin{array}{l}\text { Postoperative anal- } \\
\text { ysis of CEA preop } \\
\text { and day } 7 \text { and } \\
\text { 30-day post op }\end{array}$ & Survival & 122 & $57.56 \pm 12.24$ & 62.3 & $\begin{array}{l}\text { Significant decrease in sur- } \\
\text { vival if CEA levels remain } \\
\text { elevated in postop period. }\end{array}$ \\
\hline Sun [69] & 2009 & Taiwan & $\begin{array}{l}\text { Cohort } \\
\text { (retrospective } \\
\text { data base) }\end{array}$ & $\begin{array}{l}\text { Retrospective re- } \\
\text { view of potential } \\
\text { prognostic mark- } \\
\text { ers }\end{array}$ & $\begin{array}{l}\text { Disease-free } \\
\text { and overall } \\
\text { survival }\end{array}$ & 1,367 & $66($ IQR, 19-25) & 55.4 & $\begin{array}{l}\text { Preop CEA } \geq 5 \mathrm{ng} / \mathrm{mL} 2.38 \mathrm{x} \\
\text { more likely to die of cancer } \\
\text { than those with } \mathrm{CEA} \leq 5 \\
\mathrm{ng} / \mathrm{mL}(\mathrm{P} \leq 0.001)\end{array}$ \\
\hline $\begin{array}{l}\text { Thirunavukarasu } \\
\text { [70] }\end{array}$ & 2015 & USA & $\begin{array}{l}\text { Cohort } \\
\text { (retrospective } \\
\text { SEER database) }\end{array}$ & $\begin{array}{l}\text { Review of preop } \\
\text { CEA levels }\end{array}$ & $\begin{array}{l}\text { 5-Year overall } \\
\text { and disease- } \\
\text { specific mor- } \\
\text { tality }\end{array}$ & 16,619 & $67.4 \pm 13.8$ & 49.7 & $\begin{array}{l}\text { Elevated CEA was } \\
\text { associated with worse } \\
\text { overall and disease-spe- } \\
\text { cific mortality }\end{array}$ \\
\hline Becerra [3] & 2016 & USA & $\begin{array}{l}\text { Cohort } \\
\text { (retrospective } \\
\text { data base) }\end{array}$ & $\begin{array}{l}\text { Review of preop } \\
\text { CEA levels in } \\
\text { Stage I-III CRC }\end{array}$ & Overall survival & 69,512 & $\begin{array}{l}\text { Normal CEA: } \\
69.1 \pm 13.0 ; \\
\text { elevated CEA: } \\
70.3 \pm 12.9\end{array}$ & $\begin{array}{l}\text { Normal CEA: } \\
49.0 ; \\
\text { elevated } \\
\text { CEA: } 43.7\end{array}$ & $\begin{array}{l}\text { Preop CEA level is } \\
\text { associated with overall } \\
\text { survival }\end{array}$ \\
\hline Ozawa [4] & 2017 & Japan & $\begin{array}{l}\text { Cohort } \\
\text { (retrospective } \\
\text { National Cancer } \\
\text { Database) }\end{array}$ & $\begin{array}{l}\text { Review of preop } \\
\text { CEA levels }\end{array}$ & $\begin{array}{l}\text { 5-Year disease- } \\
\text { free survival }\end{array}$ & 7,296 & $65.3 \pm 11.2$ & 54.4 & $\begin{array}{l}\text { Preop CEA level is } \\
\text { independently associated } \\
\text { with } 5 \text {-year disease-free } \\
\text { survival }\end{array}$ \\
\hline Spindler [5] & 2017 & USA & $\begin{array}{l}\text { Cohort } \\
\text { (retrospective } \\
\text { National Cancer } \\
\text { Database) }\end{array}$ & $\begin{array}{l}\text { Review of preop } \\
\text { CEA levels in } \\
\text { Stage II CRC }\end{array}$ & $\begin{array}{l}\text { 5-Year overall } \\
\text { survival }\end{array}$ & 74,945 & $\begin{array}{l}\text { Normal CEA: } 70 \\
\text { (IQR, 59-79); } \\
\text { elevated CEA } \\
72 \text { (IQR, 60- } \\
\text { 81) }\end{array}$ & $\begin{array}{l}\text { Normal CEA: } \\
49.3 \\
\text { Elevated CEA: } \\
43.4\end{array}$ & $\begin{array}{l}\text { Preop elevated CEA is } \\
\text { associated with reduced } \\
\text { 5-year overall survival }\end{array}$ \\
\hline Kim [71] & 2017 & Korea & $\begin{array}{l}\text { Retrospective and } \\
\text { prospective } \\
\text { cohort }\end{array}$ & $\begin{array}{l}\text { To determine cutoff } \\
\text { values for preop } \\
\text { CEA in Stage III } \\
\text { CRC }\end{array}$ & $\begin{array}{l}\text { 5-Year overall } \\
\text { and disease- } \\
\text { free survival }\end{array}$ & $\begin{array}{r}\text { Retrospective } \\
\text { cohort: } 965 \text {; } \\
\text { prospective } \\
\text { cohort: } 268\end{array}$ & $\begin{array}{l}\text { Retrospective: } \\
60 \text { (range, } \\
14-84 \text { ); } \\
\text { prospective: } \\
60 \text { (range, } \\
27-80 \text { ) }\end{array}$ & $\begin{array}{l}\text { Retrospective: } \\
53.9 \\
\text { Prospective: } \\
48.9\end{array}$ & $\begin{array}{l}\text { A cutoff value of } 3 \mathrm{ng} / \mathrm{mL} \text { is } \\
\text { optimal. Preoperative CEA } \\
\text { above this level is } \\
\text { associated with inferior } \\
\text { overall and disease-free } \\
\text { survival. }\end{array}$ \\
\hline
\end{tabular}

CEA, carcinoembryonic antigen; IQR, interquartile range; preop, preoperative; postop, postoperative; CRC, colorectal cancer.

${ }^{a}$ Age: meanstandard deviation, mean \pm standard deviation, or median (range), or median (IQR).

ported symptoms [23]. Intensive CEA testing was also found to be cost effective [17]. The GILDA (Gruppo Italiano di Lavoro per la Diagnosi Anticipata) trial investigated intensive surveillance by imaging for patients with Dukes B2-C CRC [18]. In the intensive surveillance arm, recurrences were detected 5.9 months earlier, but no difference in overall survival was reported.

The threshold of serum CEA used to trigger further investiga- tions is controversial and has been addressed by a Cochrane review including 52 studies [24]. Sensitivity and specificity were $82 \%$ and $80 \%$ for a $2.5 \mathrm{ng} / \mathrm{mL}$ cutoff, $71 \%$ and $88 \%$ for $5 \mathrm{ng} / \mathrm{mL}$, and $68 \%$ and $97 \%$ for $10 \mathrm{ng} / \mathrm{mL}$, respectively. The review concluded that $10 \mathrm{ng} / \mathrm{mL}$ should be used as the threshold to trigger further investigations. Furthermore, the diagnostic accuracy of the postoperative CEA level in detecting recurrence is affected by the pre- 
Table 2. CEA and follow-up after CRC resection: selected studies

\begin{tabular}{|c|c|c|c|c|c|c|c|c|}
\hline Author & Year & Origin & Study type & Study summary & Endpoint & $\begin{array}{l}\text { No. of } \\
\text { patients }\end{array}$ & $\begin{array}{l}\text { Age (yr), median } \\
\text { (range) }\end{array}$ & $\begin{array}{l}\text { Sex ratio } \\
\text { (\%male) }\end{array}$ \\
\hline Treasure [12] & $\begin{array}{l}1984 \\
\text { (published } \\
\text { in full 2014) }\end{array}$ & UK & RCT & $\begin{array}{l}\text { Elevated CEA prompted } \\
\text { randomization to either continued } \\
\text { monitoring (conventional arm) or } \\
\text { laparotomy (aggressive) }\end{array}$ & Survival & 216 & $\begin{array}{l}\text { Conventional: } \\
62 \text { (35-75); } \\
\text { aggressive: } \\
64 \text { (33-75) }\end{array}$ & $\begin{array}{l}\text { Conventional: } 63 \\
\text { aggressive: } 56\end{array}$ \\
\hline Makela [72] & 1995 & Finland & RCT & Intensive vs. conventional follow-up & Recurrence & 106 & $\begin{array}{l}\text { Conventional: } \\
69 \text { (33-85); } \\
\text { intensive: } \\
63 \text { (33-81) }\end{array}$ & $\begin{array}{l}\text { Conventional: } 50 \\
\text { intensive: } 48\end{array}$ \\
\hline Ohlsson [20] & 1995 & Sweden & RCT & No follow-up vs. intensive follow-up & Recurrence & 107 & - & 47.7 \\
\hline Pietra [21] & 1998 & Italy & RCT & Conventional or intense follow-up & Recurrence & 207 & - & - \\
\hline Primrose [15] & 2014 & UK & RCT & $\begin{array}{l}\text { Intensive vs. minimal follow-up } \\
3 \text { different intensive groups }\end{array}$ & $\begin{array}{l}\text { Detection and } \\
\text { curative } \\
\text { treatment of } \\
\text { recurrence }\end{array}$ & 1,202 & $\begin{array}{l}\text { CT: } 69 \text { (62-76); } \\
\text { CEA: } 69 \text { (63- } \\
\text { 75); CT \& CEA: } \\
\text { 70 (64-76); } \\
\text { minimal: } 70 \\
\text { (63-75) }\end{array}$ & $\begin{array}{l}\text { CT: } 61.2 ; \text { CEA: } \\
\text { 61.3; CT \& } \\
\text { CEA: } 61.3 ; \\
\text { minimal: } 61.3\end{array}$ \\
\hline Verberne [16] & 2015 & Netherlands & $\begin{array}{l}\text { RCT (stepped } \\
\text { wedge) }\end{array}$ & Standard vs. intensive follow-up & CRC recurrence & 3,223 & 70 (26-95) & 56 \\
\hline $\begin{array}{l}\text { Wille-Jørgensen } \\
\text { [13] }\end{array}$ & On-going trial & Europe & $\begin{array}{l}\text { Multicenter } \\
\text { randomized } \\
\text { controlled trial }\end{array}$ & Intensive vs. nonintensive follow-up & $\begin{array}{l}\text { CRC recurrence } \\
\text { and mortality }\end{array}$ & - & - & - \\
\hline Lepage [14] & On-going trial & France & $\begin{array}{l}\text { Multicenter } \\
\text { randomized } \\
\text { controlled trial }\end{array}$ & Standard vs. intensive follow-up & $\begin{array}{l}\text { 5-year overall } \\
\text { survival }\end{array}$ & - & - & - \\
\hline
\end{tabular}

RCT, randomized control trial; CEA, carcinoembryonic antigen; CRC, colorectal cancer; CT, computed tomography.

Table 3. CEA and follow-up after CRC: outcome measures in selected studies

\begin{tabular}{|c|c|c|c|c|c|}
\hline Trial & Type of regimen & $\begin{array}{l}\text { Time to first } \\
\text { recurrence (mo) }\end{array}$ & $\begin{array}{l}\text { Proportion of } \\
\text { recurrences }\end{array}$ & $\begin{array}{l}\text { Overall 5-year } \\
\text { survival }\end{array}$ & Outcome summary \\
\hline $\begin{array}{l}\text { Treasure } \\
\text { (CEASL) } \\
{[12]}\end{array}$ & $\begin{array}{l}\text { All patients had clinical review } 3 / 12 \text { for } 2 \text { years and } 6 / 12 \text { for } \\
\text { the next } 3 \text { years. CEA was measured monthly for the first } \\
3 \text { years and } 3 / 12 \text { for the next } 2 \text { years. } \\
\text { Patients were randomized if the CEA became elevated ( } \geq 10 \\
\text { ng/mL). } \\
216 \text { Patients were randomized. } \\
\text { Conventional: Continued clinical monitoring with clinicians } \\
\text { blinded to increased CEA. } \\
\text { Aggressive: Clinician screen for widespread metastatic } \\
\text { disease examinations and CXR. If not found, patient had a } \\
\text { laparotomy to look for recurrence. }\end{array}$ & $\begin{array}{l}\text { Median time from } \\
\text { primary surgery to } \\
\text { CEA increases and } \\
\text { randomization was } \\
403 \text { days (range, } \\
\text { 103-1,754) }\end{array}$ & $\begin{array}{c}\text { Conventional: } 82 \% \text {; } \\
\text { aggressive: } 77 \%\end{array}$ & $\begin{array}{l}\text { Not reported. End of } \\
\text { trial figures below } \\
\text { Conventional: } 82 \% \\
\text { died } \\
\text { Aggressive: } 84 \% \\
\text { died }\end{array}$ & $\begin{array}{l}\text { Second look laparotomy } \\
\text { in the event of CEA } \\
\text { elevation did not } \\
\text { improve survival. }\end{array}$ \\
\hline Makela [72] & $\begin{array}{l}\text { Clinic review for all } 3 / 12 \text { for } 2 \text { years, the } 6 / 12 \text { for } 3 \text { years } \\
\text { with history, examination, complete blood cell counts, } \\
\text { faecal occult bloods, CEA and CXR. } \\
\text { USS liver every } 6 / 12 \text { and CT every year. } \\
\text { In addition: Conventional: rigid sigmoidoscopy at each visit } \\
\text { for those who had undergone surgery for rectal and } \\
\text { sigmoid cancers, and a barium enema was done for all } \\
\text { patients at } 12 \text { months and once a year thereafter; Intensive: } \\
\text { colonoscopy } 3 \text { months after the surgery to ensure a clean } \\
\text { colon and once a year thereafter on allpatients }\end{array}$ & $\begin{array}{l}\text { Conventional: } \\
15 \pm 10 \text {; } \\
\text { intensive: } \\
10 \pm 5\end{array}$ & $\begin{array}{l}\text { Conventional: } 39 \% \text {; } \\
\text { intensive: } 42 \%\end{array}$ & $\begin{array}{l}\text { Conventional: } 54 \% \text {; } \\
\text { intensive: } 59 \%\end{array}$ & $\begin{array}{l}\text { Intensive follow-up leads } \\
\text { to earlier detection of } \\
\text { recurrence. } \\
\text { Most common sign } \\
\text { indicating recurrence } \\
\text { was CEA elevation in } \\
\text { both groups. }\end{array}$ \\
\hline
\end{tabular}


Table 3. Continued

\begin{tabular}{llcccc}
\hline \multicolumn{1}{c}{ Type of regimen } & $\begin{array}{c}\text { Time to first } \\
\text { recurrence (mo) }\end{array}$ & $\begin{array}{c}\text { Proportion of } \\
\text { recurrences }\end{array}$ & $\begin{array}{c}\text { Overall 5-year } \\
\text { survival }\end{array}$ & Outcome summary \\
\hline Ohlsson [20] & $\begin{array}{l}\text { None/Control: No FU } \\
\text { Intensive: clinical exam, rigid sig, colonoscopy, CT pelvis (in } \\
\text { patients with APR), pulmonary X-ray, liver function tests, }\end{array}$ & - & $\begin{array}{c}\text { Control: 33\%; } \\
\text { intensive: } 32 \%\end{array}$ & $\begin{array}{c}\text { Control: 67\%; } \\
\text { intensive: } 75 \%\end{array}$ & $\begin{array}{c}\text { Intensive follow-up did } \\
\text { not improve survival. }\end{array}$ \\
\end{tabular}

patients with APR), pulmonary $X$-ray, liver function tests, CEA and faecal hemoglobin at 3-, 6-, 9-, 12-, 15-, 18-, 21-, 24-, 30-, 36-, 42-, 48-, and 60-month intervals

\begin{tabular}{|c|c|c|c|}
\hline Pietra [21] & $\begin{array}{l}\text { Conventional: clinical exam + CEA and USS at } 6 / 12 \text { intervals } \\
\text { for } 1 \text { year then annually thereafter. } \\
\text { All patients received yearly CXR, colonoscopy and CT. } \\
\text { Intensive: As above, but with intervals } 3 / 12 \text { for } 2 \text { years then } \\
6 / 12 \text { for } 3 \text { years }\end{array}$ & $\begin{array}{l}\text { Conventional: } \\
20.2 \pm 6.1 \\
\text { ilntensive: } \\
10.3 \pm 2.7\end{array}$ & $\begin{array}{l}\text { Conven- } \\
\text { tional:19.4\%; } \\
\text { intensive: } 25.2 \%\end{array}$ \\
\hline $\begin{array}{l}\text { Primrose } \\
\text { (FACS) [15] }\end{array}$ & $\begin{array}{l}\text { Control: CT at } 12-18 \text { months or if symptomatic } \\
\text { Intensive: CT: Scan of the chest, abdomen, and pelvis every } \\
6 \text { months for } 2 \text { years, then annually for } 3 \text {. CEA: CEA every } \\
3 \text { months for } 2 \text { years, then every } 6 \text { months for } 3 \text { years, } \\
\text { with a single CT scan at } 12 \text { to } 18 \text { months if requested at } \\
\text { study entry by hospital clinician. CT and CEA: Both of the }\end{array}$ & - & $\begin{array}{l}\text { Cancer recurrence } \\
\text { in } 16.6 \% \text { of } \\
\text { patients, } 5.9 \% \text { of } \\
\text { these surgically } \\
\text { treated with } \\
\text { curative intent }\end{array}$ \\
\hline
\end{tabular}
regimes combined.

All had colonoscopy at 2 and 5 years

Rosati (GILDA) Control: Clinical review and CEA every 3 months for 2 years, In [18] then every 6 months for 3 years. Colonoscopy at 1 year. Liver USS at 4 months and 16 months.

Intensive: Clinical review and CEA as per control group. CBC and CA 19-9 included with CEA. Colonoscopy and CXR every 12 months. Liver USS every 4 months for 16 months, then yearly

\author{
tensive surveillance Overall recurrence \\ had earlier detection rate: $20.4 \%$; \\ of 5.9 months (95\% control: $18.7 \%$; \\ Cl, 2.71-9.11) \\ intensive: $22 \%$
}

Control: $52.7 \%$; intensive: $47.8 \%$

int $47.8 \%$

Conventional: 58.3\%; intensive: $73.1 \%$
Intense follow-up leads to earlier detection of recurrent disease and improved survival.

Intensive follow-up (any group) detected recurrence earlier and increased rate of curative surgical treatment. No advantage when using CT and CEA in combination. Could not demonstrate survival advantage.

Intensive surveillance detected recurrences earlier, but there was no difference in overall survival. Quality of life was not affected by surveillance strategy.

Verberne Control: 5-year follow-up. Clinic every 6/12 for 3 years, then Specific time interval Overall recurrence (CEAWatch) annually thereafter. Liver USS and CXR at each visit. CEA [23] every 3 to 6 months for 3 years and annually thereafter. Intensive: bimonthly CEA and yearly imaging for 3 years. CEA every $3 / 12$ for next 2 years. Annual clinic review with imaging of chest and abdomen for 3 years. If $20 \%$ increase in CEA, another blood sample was drawn 4 weeks later. If a consecutive rise, CT scan of chest and abdomen was advised. Normal value was considered to be $\leq 2.5 \mathrm{ng} / \mathrm{mL}$ not given; however, the authors stated that the time to diagnosis of recurrent disease decreased with the intensive follow-up protocol as compared to the control protocol (HR, 1.45; $95 \% \mathrm{Cl}$, 1.08-1.95; $\mathrm{P}=$ $0.013)$ rate: $7.5 \%$; control: $3.6 \%$; intensive: $4.4 \%$
No difference in OS or DFS between 2 arms. Survival significantly worse when detected by patients self-report rather than CEA or imaging.
An intensified protocol with CEA monitoring and assessment of CEA rise rather than absolute value detected recurrences earlier than the standard protocol. This does not affect overall or disease-free survival.

\begin{tabular}{|c|c|c|c|c|c|}
\hline $\begin{array}{l}\text { Wille- } \\
\text { Jørgensen } \\
\text { (COLOFOL) } \\
{[13]}\end{array}$ & $\begin{array}{l}\text { Nonintensive: CT scan of liver and lungs (or CT of liver + } \\
\text { plain X-ray of lungs) + CEA after } 12 \text { and } 36 \text { months. } \\
\text { Intensive: CT scan of liver and lungs (or CT of liver + plain } \\
\text { X-ray of lungs) + CEA after } 6,12,18,24 \text {, and } 36 \text { months }\end{array}$ & - & - & - & $\begin{array}{l}\text { Recruitment ended } 2015 . \\
\text { Results awaited. }\end{array}$ \\
\hline $\begin{array}{l}\text { Lepage } \\
\text { (PRODIGE } \\
\text { 13) [14] }\end{array}$ & $\begin{array}{l}\text { Standard: Abdo USS every } 3 / 12 \text { for } 3 \text { years, } 6 / 12 \text { for } 2 \\
\text { years, then annually. CXR ever } 6 / 12 \text { for } 3 \text { years, then } \\
\text { annually. } \\
\text { Intensive: A CT thorax/abdominal/pelvis alternating with } \\
\text { abdominal USS every } 3 / 12 \text { for } 3 \text { years, then every } 6 / 12 \\
\text { for } 2 \text { years. CEA every } 3 / 12 \text { for } 3 \text { years, then } 6 / 122 \text { years }\end{array}$ & - & - & - & $\begin{array}{l}\text { Recruitment ended. } \\
\text { Results awaited }\end{array}$ \\
\hline
\end{tabular}

FACS, Follow-up After Colorectal Surgery; GILDA, Gruppo Italiano di Lavoro per la Diagnosi Anticipata; CEAWatch, Carcino-Embryonic Antigen Watch; CEA, carcinoembryonic antigen; CRC, colorectal cancer; CT, computed tomography; FU, follow-up; CXR, chest X-Ray; USS, UltraSound Scan; CBC, complete blood count; Cl, confidence interval; HR, hazard ratio; OS, overall survival; DFS, disease-free survival. 
operative value. With a threshold of $5 \mathrm{ng} / \mathrm{mL}$ at 6 months, in patients with curatively resected colon cancer and normal preoperative CEA, the diagnostic accuracy for recurrence was $89.1 \%$, in contrast to patients with an elevated preoperative CEA in whom the accuracy was 58.4\%; an increased threshold of $>8 \mathrm{ng} / \mathrm{mL}$ in this latter group improved diagnostic accuracy to $75.6 \%$ [25].

The hypothesis that CEA level reflects tumor burden in patients with metastatic disease has also been studied by assessing treatment response to chemotherapy. Huang et al. [26] retrospectively analysed 447 patients with metastatic CRC who had undergone resection of the primary tumor and adjuvant chemotherapy. The ratio of posttreatment (after 6 courses of chemotherapy) to pretreatment CEA was strongly correlated with the radiological response and with overall survival [26]. Similarly, in patients with metastatic CRC receiving first-line chemotherapy, there were distinct CEA level slopes according to type of radiological response i.e., progression, partial response, and stable disease [27], suggesting that CEA levels and ratios have a role in the early assessment of treatment response in stage IV CRC. In the FIRE-3 trial, the CEA trend reflected response to targeted therapy [28] in patients with (K)RAS wild-type metastatic CRC. First-line FOLFIRI plus cetuximab gave better overall survival than FOLFIRI plus bevacizumab (28.7 months vs. 25.0 months) [29], with a corresponding faster and greater decrease in CEA level. In the cetuximab arm, CEA responders, defined as a decrease of at least $75 \%$, had better disease-free and overall survivals than CEA nonresponders.

At the cellular level, a correlation between the immunohistochemical status of CEA staining and the serum CEA level was found in colorectal metastases, but not in the primary tumors [30], suggesting that serum CEA levels are influenced both by the production of CEA in tumor cells and by its release into the bloodstream. Positive staining for CEA in metastatic tissue also carried a worse survival. Overexpression of CEA has been reported to inhibit Natural Killer cells and cytotoxic lymphocytes, which may dampen the immune response to metastases [31].

\section{What to do for a patient with a raised CEA and no history of CRC}

Whilst no specific trials have addressed what to do for a patient with a raised CEA and no history of CRC, studies have evaluated CEA in screening and diagnosis (Table 4). In patients with elevated CEA, the chance of finding CRC is increased (4.6\% vs. 1.3\%) [32]. CEA is also a predictor of other diseases, including other cancers, diabetes, chronic lung disease and liver disease [33]. A combination of biomarkers, including CEA, CA 19-9, prostate-specific antigen, and CA125, increases the sensitivity of CEA as a screening modality $[34,35]$. In a patient with raised CEA, a detailed history and clinical assessment are likely to be the most important first steps. No evidence was found to support CEA being used as a screening tool.

Table 4. CEA and screening/diagnosis: selected studies

\begin{tabular}{|c|c|c|c|c|c|c|c|c|c|}
\hline Author & Year & Origin & Study type & $\begin{array}{c}\text { Asymptomatic } \\
\text { vs. symptomatic }\end{array}$ & Endpoint & No. of patients & $\begin{array}{l}\text { Age (yr), } \\
\text { median }\end{array}$ & $\begin{array}{l}\text { Sex ratio } \\
\text { (\%male) }\end{array}$ & Outcome summary \\
\hline Lee [32] & 2011 & Korea & Case control & Asymptomatic & $\begin{array}{l}\text { Detection of } \\
\text { colorectal cancer }\end{array}$ & $\begin{array}{l}546 \\
\text { (A) CEA } \geq 5 \mathrm{ng} / \mathrm{mL} \\
\text { (B) CEA } \leq 5 \mathrm{ng} / \mathrm{mL}\end{array}$ & $\begin{array}{l}\text { (A) } 56 \\
\text { (B) } 54\end{array}$ & $\begin{array}{l}\text { A) } 77 \\
\text { B) } 73.4\end{array}$ & $\begin{array}{l}\text { 4.6\% of high CEA group had CRC } \\
\text { compared to } 1.3 \% \text { of normal } \\
\text { CEA group. } \\
\text { CEA more likely to be elevated in } \\
\text { advanced colorectal cancer. }\end{array}$ \\
\hline Nielsen [33] & 2011 & Denmark & Case control & Symptomatic & $\begin{array}{l}\text { Detection of } \\
\text { colorectal cancer }\end{array}$ & 4,509 & 61 & 45.9 & $\begin{array}{l}\text { CEA more likely to be elevated in } \\
\text { advanced colorectal cancer. } \\
\text { Median of } 8.1 \mathrm{ng} / \mathrm{mL} \text { in stage } 4 \\
\text { disease }\end{array}$ \\
\hline Wild [35] & 2010 & Germany & Case control & Mixed & $\begin{array}{l}\text { Comparison of } \\
\text { serum-biomarker } \\
\text { panel with Faecal } \\
\text { occult blood } \\
\text { testing }\end{array}$ & $\begin{array}{l}1,027 \\
\text { (A) CRC } 301 \\
\text { (B) Gl disease control } \\
104 \\
\text { (C) Adenoma } 143 \\
\text { (D) Other disease } 141 \\
\text { (E) Other malignancy } \\
176\end{array}$ & $\begin{array}{l}\text { (A) } 67 \\
\text { (B) } 62 \\
\text { (C) } 66 \\
\text { (D) } 62 \\
\text { (E) } 64\end{array}$ & $\begin{array}{l}\text { (A) } 52.2 \\
\text { (B) } 39.1 \\
\text { (C) } 58.7 \\
\text { (D) } 46.1 \\
\text { (E) } 42.6\end{array}$ & $\begin{array}{l}\text { CEA more likely to be elevated in } \\
\text { advanced colorectal cancer. } \\
88.2 \% \text { sensitivity in stage } 4 \\
\text { disease. } \\
\text { CEA, seprase, CYFRA } 21-1 \text {, } \\
\text { ferritin and anti-p53 biomarker } \\
\text { combination was comparable } \\
\text { with faecal immunochemical } \\
\text { testing with } 82.4 \% \text { versus } \\
81.8 \% \text { at } 95 \% \text { specificity, }\end{array}$ \\
\hline Wen [34] & 2015 & Taiwan & Case control & Mixed & $\begin{array}{l}\text { Detection of cancer } \\
\text { using panel of } 8 \\
\text { markers }\end{array}$ & 41,516 & & & $\begin{array}{l}\text { CEA sensitivity } 53.8 \% \text {. Increases, } \\
\text { when used in combination as } \\
\text { panel of } 8 \text { biomarkers, to } \\
76.9 \%\end{array}$ \\
\hline
\end{tabular}

CEA, carcinoembryonic antigen; CRC, colorectal cancer; Gl, gastrointestinal. 


\section{DISCUSSION}

The available evidence supports the use of CEA in surveillance of CRC, particularly in postoperative follow-up. However, no evidence supports its use in screening and diagnosis of CRC, as CEA may be elevated in patients with other pathologies $[2,36-38]$ and many CRC patients will have a normal CEA. Serum levels $>3-5$ $\mathrm{ng} / \mathrm{mL}$ are deemed to be elevated $[39,40]$. Higher baseline levels occur in males, smokers and the elderly $[39,40]$. Elevated CEA levels have been associated with a number of benign and malignant conditions (Table 5). CEA is used most frequently in CRC, but it is also a tumor marker in mucinous adenocarcinomas of the endocervix and ovary, as well as in keratinising squamous cell carcinomas of the cervix [41]. CEA levels $>10 \mathrm{ng} / \mathrm{mL}$ or trending upwards are more commonly associated with malignant conditions [40-43]. Levels $>20 \mathrm{ng} / \mathrm{mL}$ are suspicious for metastatic disease [42, 44-46]. As CEA is primarily metabolized in the liver, hepatic dysfunction and biliary obstruction can be associated with raised CEA levels.

In view of the high first-pass hepatic metabolism of CEA $(\geq 90 \%)$, very high CEA levels tend to be due to CEA-producing tumors or metastases outside the portal venous drainage territory or to locally advanced tumors within the portal venous system's

Table 5. Conditions associated with elevated carcinoembryonic antigen (CEA) level

\begin{tabular}{|c|c|}
\hline Nonmalignant & Malignant \\
\hline Smoking & Tumors associated with high CEA expression \\
\hline Infections & Colorectal $^{\mathrm{a}}$ \\
\hline Peptic ulcer disease & Ovarian $^{\mathrm{a}}$ \\
\hline Inflammatory bowel disease & Cervical $^{\mathrm{a}}$ \\
\hline Pancreatitis & Lung \\
\hline Hypothyroidism & Oesophageal \\
\hline Liver cirrhosis, hepatitis & Gastric \\
\hline Benign breast conditions & Small intestinal \\
\hline Other benign tumors usually & Hepatobiliary \\
\hline in organs where the & Pancreatic \\
\hline cancers are associated & Breast \\
\hline \multirow[t]{9}{*}{ with raised CEA } & Medullary \\
\hline & Other CEA-expressing tumors \\
\hline & Choriocarcinoma \\
\hline & Osteosarcoma \\
\hline & Retinoblastoma \\
\hline & Hepatoma \\
\hline & Melanoma \\
\hline & Lymphoma \\
\hline & Urinary bladder, prostate and renal cell carcinoma \\
\hline
\end{tabular}

drainage territory. Tumor differentiation also affects CEA level [45-47], with $80 \%$ of well-differentiated CRCs producing CEA and only $60 \%$ of poorly-differentiated tumors produce it [48], making surveillance less reliable. Following CRC resection in patients with normal hepatic function, a 95\% reduction to the steadstate postoperative CEA level takes five half-lives, i.e., 35 days [39, $44,47]$.

CEA levels correlate with prognosis [49-51]. In CRC, elevated preoperative CEA level $(>5 \mathrm{ng} / \mathrm{mL})$ is associated with a higher recurrence rate and disease-related mortality [50-54]. A postoperative CEA decrease is also a prognostic indicator $[55,56]$, predicting improved overall survival and disease-free survival [28]. This also applies to those having liver surgery for colorectal metastases [57]. CEA level has also been correlated with the presence of circulating cancer cells [54].

The role of pretreatment CEA level in predicting response to chemotherapy or radiotherapy is uncertain, with some studies showing no correlation [58] and with others showing that, compared to CEA $<3 \mathrm{ng} / \mathrm{mL}$, an elevated pretreatment CEA ( $>9 \mathrm{ng} /$ $\mathrm{mL}$ ) was associated with a poor response to long-course chemoradiotherapy [59]. Reduction of CEA following neoadjuvant chemoradiotherapy for rectal cancer has prognostic significance [60], with CEA $\leq 5 \mathrm{ng} / \mathrm{mL}$ being correlated with increased complete clinical and pathological response and better overall and disease-free survivals. High posttreatment CEA levels may, therefore, identify patients for adjuvant treatment and intensive surveillance, and may perhaps be a relative contraindication to 'watch and wait' in patients with apparently complete clinical response.

Surveillance recommendations for CEA in CRC patients vary. The American Society of Clinical Oncology (ASCO) recommends preoperative CEA and postoperative CEA every 3-6 months for at least 5 years $[61,62]$. The UK National Institute of Clinical Excellence recommends CEA levels be measured every 6 months for at least 3 years [63]. In addition, ASCO [61] recommends CEA for monitoring the response of metastatic disease to systemic therapy. The CEA doubling time is affected by rate of growth of metastases and by site of recurrence $[64,65]$.

\section{CRC surveillance: management of patients with elevated CEA levels}

A patient with an elevated or progressively rising CEA level with previous CRC should be investigated for recurrent disease (Fig. 2), initially with cross-sectional imaging (CT scan or positron emission tomography-CT [PET-CT]) of the chest, abdomen and pelvis, and not colonoscopy because of CEA's first-pass metabolism. Both the British Royal Society of Radiology [66] and the US oncology guidelines [67] suggest only performing a PET-CT when other imaging has been normal. If these investigations are negative, a repeat CEA level with clinical review at 3 months is suggested. If the CEA level remains stable without clinical evidence of recurrence, continued CEA measurements every 3 months and clinical review are encouraged. If the CEA level is increasing or 


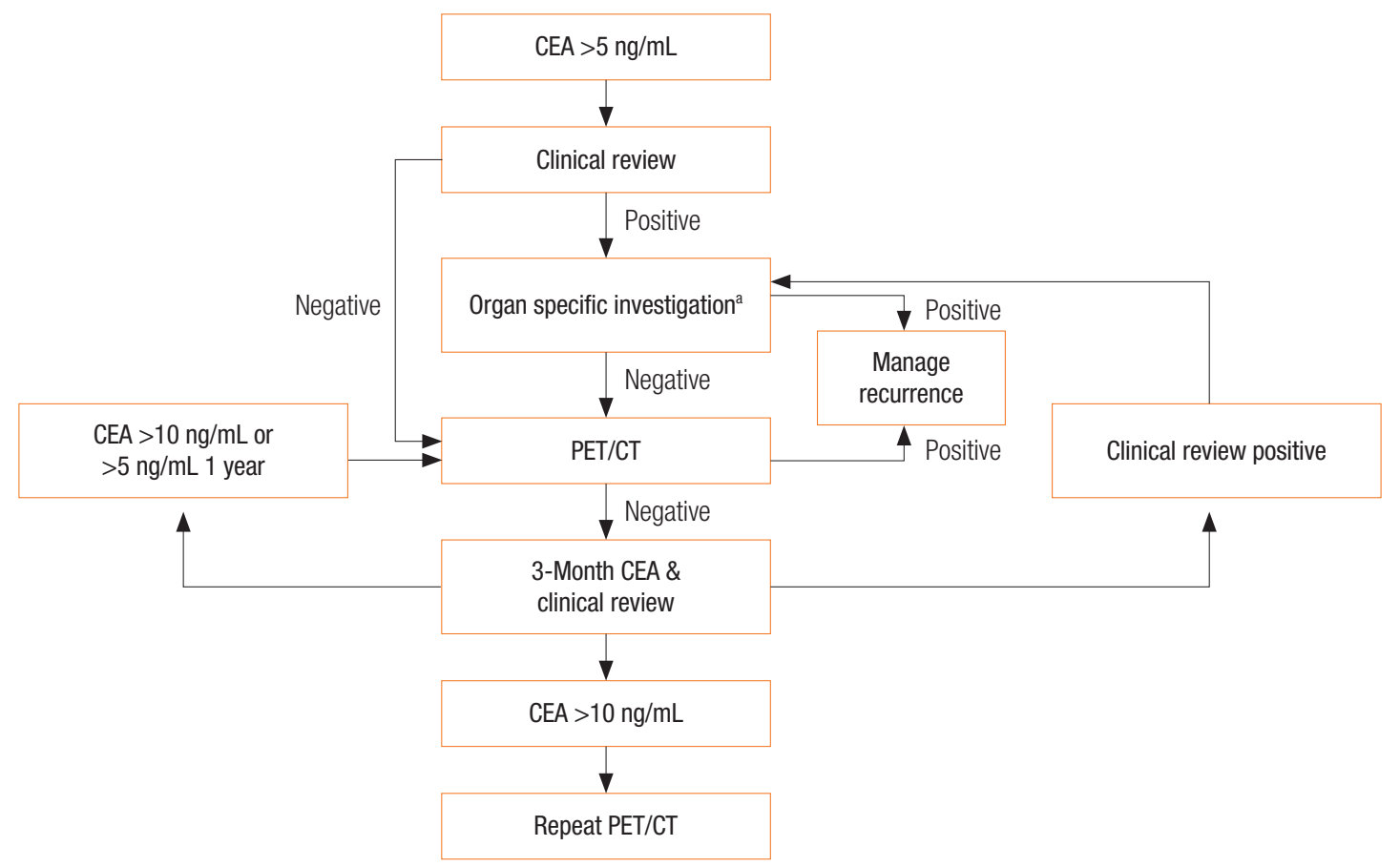

Fig. 2. Algorithm 1: Investigation pathway for a patient with a raised carcinoembryonic antigen (CEA) with a previous history of a CEA-expressing cancer. a'Organ-specific investigations: tumor markers, CT scan, colonoscopy, gastroscopy, mammography, cystoscopy, Ultrasound Scan (US), bone scan, biopsy, other test as required. PET/CT, positron emission tomography-computed tomography.

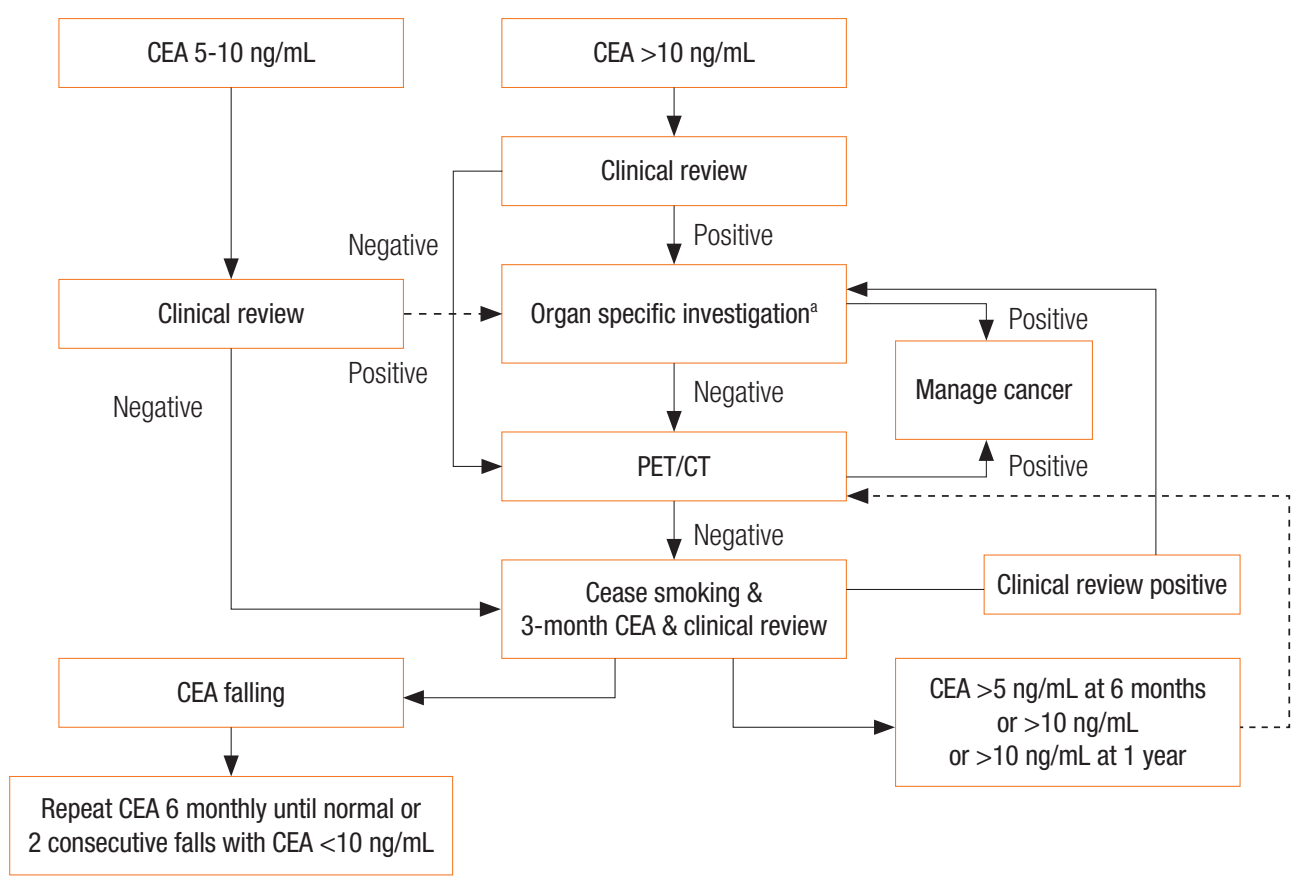

Fig. 3. Algorithm 2: Investigation pathway for a patient with a de novo raised carcinoembryonic antigen (CEA). ${ }^{\mathrm{a} O r g a n-s p e c i f i c ~ i n v e s t i g a t i o n s: ~}$ tumor markers, CT scan, colonoscopy, gastroscopy, mammography, cystoscopy, US, bone scan, biopsy, other test as required. Clinical review includes: a full history and examination of the thyroid, breast, thorax, abdomen and pelvis, visual field testing, fundoscopy, long bones examination. Look for melanoma. In females, cervical examination. In males, a prostate examination. PET/CT, positron emission tomography-computed tomography. 


\section{Coloproctology Claire Hall, et al.}

$>10 \mathrm{ng} / \mathrm{mL}$ or if clinical evidence of recurrence is found, repeat cross-sectional imaging is suggested.

\section{Patients referred with de novo elevated CEA}

While CEA should not be used as a diagnostic tool, it often is by the overexuberant health professional. This then raises the dilemma of determining if the elevated CEA is significant, in the absence of a previous history of CRC (Fig. 3). If the patient has a history of previous CEA-producing malignancy (Table 5), the patient should be evaluated in accordance with that particular malignancy.

In the absence of a history of a previous CEA-producing tumor, evaluation begins with a thorough history and clinical examination, looking for relevant symptoms and signs of CEA-producing benign and malignant conditions (Table 5), and smoking history. Further investigations would include repeat CEA, full blood count, and iron studies, liver and renal function tests, determinations of the CA 125 and calcitonin levels, and so on, as indicated from the clinical review.

If the clinical review does not raise any suspicion of a particular disease process and CEA is $<10 \mathrm{ng} / \mathrm{mL}$, no further investigations are recommended at this stage. The patient should be advised to stop smoking for cardiovascular and respiratory health. Determination of the CEA level and a clinical review should be repeated at 3 months. If the level falls, determination of the CEA level and a clinical review should be repeated at 6-month intervals until the CEA level returns to normal or until 2 consecutive decreases are noted. If, however, after 3-6 intervals, the CEA level remains above $5 \mathrm{ng} / \mathrm{mL}$ or if the level exceeds $10 \mathrm{ng} / \mathrm{mL}$ at any stage, further investigations (CT scan, PET-CT or organ-specific investigations) are indicated.

If the CEA level is greater than $10 \mathrm{ng} / \mathrm{mL}$ at the time of presentation, a PET-CT or whole-body CT can be used to look for primary and/or secondary malignancy, unless clinical review indicates a likely site of malignancy to guide a more specific investigations Depending on access and local costs, using a PET-CT scan before organ-specific testing might be more cost effective. If these preliminary tests are negative, a repeat CEA should be performed 3 months later with a clinical review. The clinical review is more important at this stage. A CEA level persistently $>10 \mathrm{ng} / \mathrm{mL}$ at 1 year requires repeat investigation. Rising CEA levels $>10 \mathrm{ng} / \mathrm{mL}$ or levels $>20 \mathrm{ng} / \mathrm{mL}$ require investigation every year until the underlying cause is detected.

In the clinical scenario of patients with de novo elevated CEA, our practice would be to investigate with whole-body PET-CT before organ-specific investigations, unless clinical evidence suggesting a specific site for the malignancy is found. If PET-CT scanning is not available, we suggest whole-body CT.

\section{CONCLUSION}

Current evidence suggests CEA has a role in the prognostication and treatment planning for and the surveillance of patients with CRC. The use of algorithms will help guide how patients presenting with elevated CEA should be further elevated.

\section{CONFLICT OF INTEREST}

No potential conflict of interest relevant to this article was reported.

\section{REFERENCES}

1. Gold P, Freedman SO. Demonstration of tumor-specific antigens in human colonic carcinomata by immunological tolerance and absorption techniques. J Exp Med 1965;121:439-62.

2. Thomson DM, Krupey J, Freedman SO, Gold P. The radioimmunoassay of circulating carcinoembryonic antigen of the human digestive system. Proc Natl Acad Sci U S A 1969;64:161-7.

3. Becerra AZ, Probst CP, Tejani MA, Aquina CT, González MG, Hensley BJ, et al. Evaluating the prognostic role of elevated preoperative carcinoembryonic antigen levels in colon cancer patients: results from the national cancer database. Ann Surg Oncol 2016;23:1554-61.

4. Ozawa H, Kotake K, Hosaka M, Hirata A, Nakagawa Y, Fujita S, Sugihara K. Incorporation of serum carcinoembryonic antigen levels into the prognostic grouping system of colon cancer. Int J Colorectal Dis 2017;32:821-9.

5. Spindler BA, Bergquist JR, Thiels CA, Habermann EB, Kelley SR, Larson DW, et al. Incorporation of CEA improves risk stratification in stage II colon cancer. J Gastrointest Surg 2017;21:770-7.

6. Katoh H, Yamashita K, Kokuba Y, Satoh T, Ozawa H, Hatate K, et al. Diminishing impact of preoperative carcinoembryonic antigen (CEA) in prognosis of Dukes' $\mathrm{C}$ colorectal cancer. Anticancer Res 2008;28(3B):1933-41.

7. Kim JY, Kim NK, Sohn SK, Kim YW, Kim KJ, Hur H, et al. Prognostic value of postoperative CEA clearance in rectal cancer patients with high preoperative CEA levels. Ann Surg Oncol 2009; 16:2771-8.

8. Abe S, Kawai K, Ishihara S, Nozawa H, Hata K, Kiyomatsu T, et al. Prognostic impact of carcinoembryonic antigen and carbohydrate antigen 19-9 in stage IV colorectal cancer patients after R0 resection. J Surg Res 2016;205:384-92.

9. Probst CP, Becerra AZ, Aquina CT, Tejani MA, Hensley BJ, González MG, et al. Watch and Wait?--elevated pretreatment CEA Is associated with decreased pathological complete response in rectal cancer. J Gastrointest Surg 2016;20:43-52.

10. Mokhles S, Macbeth F, Farewell V, Fiorentino F, Williams NR, Younes RN, et al. Meta-analysis of colorectal cancer follow-up after potentially curative resection. Br J Surg 2016;103:1259-68.

11. Jeffery M, Hickey BE, Hider PN, See AM. Follow-up strategies for patients treated for non-metastatic colorectal cancer. Cochrane Database Syst Rev 2016 Nov 24;11:CD002200.

12. Treasure T, Monson K, Fiorentino F, Russell C. The CEA Second- 
Look Trial: a randomised controlled trial of carcinoembryonic antigen prompted reoperation for recurrent colorectal cancer. BMJ Open 2014;4:e004385.

13. Wille-Jørgensen P, Laurberg S, Påhlman L, Carriquiry L, Lundqvist N, Smedh K, et al. An interim analysis of recruitment to the COLOFOL trial. Colorectal Dis 2009;11:756-8.

14. Lepage C, Phelip JM, Cany L, Faroux R, Manfredi S, Ain JF, et al. Effect of 5 years of imaging and CEA follow-up to detect recurrence of colorectal cancer: The FFCD PRODIGE 13 randomised phase III trial. Dig Liver Dis 2015;47:529-31.

15. Primrose JN, Perera R, Gray A, Rose P, Fuller A, Corkhill A, et al. Effect of 3 to 5 years of scheduled CEA and CT follow-up to detect recurrence of colorectal cancer: the FACS randomized clinical trial. JAMA 2014;311:263-70.

16. Verberne CJ, Zhan Z, van den Heuvel E, Grossmann I, Doornbos $\mathrm{PM}$, Havenga $\mathrm{K}$, et al. Intensified follow-up in colorectal cancer patients using frequent Carcino-Embryonic Antigen (CEA) measurements and CEA-triggered imaging: Results of the randomized “CEAwatch” trial. Eur J Surg Oncol 2015;41:1188-96.

17. Verberne CJ, Wiggers T, Grossmann I, de Bock GH, Vermeulen KM. Cost-effectiveness of a carcinoembryonic antigen (CEA) based follow-up programme for colorectal cancer (the CEA Watch trial). Colorectal Dis 2016;18:091-6.

18. Rosati G, Ambrosini G, Barni S, Andreoni B, Corradini G, Luchena $G$, et al. A randomized trial of intensive versus minimal surveillance of patients with resected Dukes B2-C colorectal carcinoma. Ann Oncol 2016;27:274-80.

19. Makela JT, Laitinen SO, Kairaluoma MI. Five-year follow-up after radical surgery for colorectal cancer. Results of a prospective randomized trial. Arch Surg 1995;130:1062-7.

20. Ohlsson B, Breland U, Ekberg H, Graffner H, Tranberg KG. Follow-up after curative surgery for colorectal carcinoma. Randomized comparison with no follow-up. Dis Colon Rectum 1995;38: 619-26.

21. Pietra N, Sarli L, Costi R, Ouchemi C, Grattarola M, Peracchia A. Role of follow-up in management of local recurrences of colorectal cancer: a prospective, randomized study. Dis Colon Rectum 1998;41:1127-33.

22. Shinkins B, Nicholson BD, Primrose J, Perera R, James T, Pugh S, et al. The diagnostic accuracy of a single CEA blood test in detecting colorectal cancer recurrence: Results from the FACS trial. PLoS One 2017;12:e0171810.

23. Verberne CJ, Zhan Z, van den Heuvel ER, Oppers F, de Jong AM, Grossmann I, et al. Survival analysis of the CEAwatch multicentre clustered randomized trial. Br J Surg 2017;104:1069-77.

24. Nicholson BD, Shinkins B, Pathiraja I, Roberts NW, James TJ, Mallett S, et al. Blood CEA levels for detecting recurrent colorectal cancer. In: Cochrane Collaboration. Cochrane Database of Systematic Reviews. Chichester (UK): John Wiley \& Sons; 2015.

25. Saito G, Sadahiro S, Kamata H, Miyakita H, Okada K, Tanaka A, et al. Monitoring of serum carcinoembryonic antigen levels after curative resection of colon cancer: cutoff values determined ac- cording to preoperative levels enhance the diagnostic accuracy for recurrence. Oncology 2017;92:276-82.

26. Huang SC, Lin JK, Lin TC, Chen WS, Yang SH, Wang HS, et al. Concordance of carcinoembryonic antigen ratio and response evaluation criteria in solid tumors as prognostic surrogate indicators of metastatic colorectal cancer patients treated with chemotherapy. Ann Surg Oncol 2015;22:2262-8.

27. Michl M, Koch J, Laubender RP, Modest DP, Giessen C, Schulz $\mathrm{Ch}$, et al. Tumor markers CEA and CA 19-9 correlate with radiological imaging in metastatic colorectal cancer patients receiving first-line chemotherapy. Tumour Biol 2014;35:10121-7.

28. Michl M, Stintzing S, Fischer von Weikersthal L, Decker T, Kiani A, Vehling-Kaiser U, et al. CEA response is associated with tumor response and survival in patients with KRAS exon 2 wild-type and extended RAS wild-type metastatic colorectal cancer receiving first-line FOLFIRI plus cetuximab or bevacizumab (FIRE-3 trial). Ann Oncol 2016;27:1565-72.

29. Heinemann V, von Weikersthal LF, Decker T, Kiani A, VehlingKaiser U, Al-Batran SE, et al. FOLFIRI plus cetuximab versus FOLFIRI plus bevacizumab as first-line treatment for patients with metastatic colorectal cancer (FIRE-3): a randomised, openlabel, phase 3 trial. Lancet Oncol 2014;15:1065-75.

30. Saito G, Sadahiro S, Okada K, Tanaka A, Suzuki T, Kamijo A. Relation between carcinoembryonic antigen levels in colon cancer tissue and serum carcinoembryonic antigen levels at initial surgery and recurrence. Oncology 2016;91:85-9.

31. Gray-Owen SD, Blumberg RS. CEACAM1: contact-dependent control of immunity. Nat Rev Immunol 2006;6:433-46.

32. Lee JH, Hong SP, Jeon TJ, Kang GH, Choi WC, Jeon SM, et al. Should a colonoscopy be recommended for healthy individuals with increased carcinoembryonic antigen levels? A case-control study. Dig Dis Sci 2011;56:2396-403.

33. Nielsen HJ, Brünner N, Jorgensen LN, Olsen J, Rahr HB, Thygesen $\mathrm{K}$, et al. Plasma TIMP-1 and CEA in detection of primary colorectal cancer: a prospective, population based study of 4509 high-risk individuals. Scand J Gastroenterol 2011;46:60-9.

34. Wen YH, Chang PY, Hsu CM, Wang HY, Chiu CT, Lu JJ. Cancer screening through a multi-analyte serum biomarker panel during health check-up examinations: Results from a 12-year experience. Clin Chim Acta 2015;450:273-6.

35. Wild N, Andres H, Rollinger W, Krause F, Dilba P, Tacke M, et al. A combination of serum markers for the early detection of colorectal cancer. Clin Cancer Res 2010;16:6111-21.

36. Hammarström S. The carcinoembryonic antigen (CEA) family: structures, suggested functions and expression in normal and malignant tissues. Semin Cancer Biol 1999;9:67-81.

37. Benchimol S, Fuks A, Jothy S, Beauchemin N, Shirota K, Stanners CP. Carcinoembryonic antigen, a human tumor marker, functions as an intercellular adhesion molecule. Cell 1989;57:327-34.

38. Yap BS, Yap HY, Fritsche HA, Blumenschein G, Bodey GP. CSF carcinoembryonic antigen in meningeal carcinomatosis from breast cancer. JAMA 1980;244:1601-3. 


\section{Coloproctology Claire Hall, et al.}

39. Herbeth B, Bagrel A. A study of factors influencing plasma CEA levels in an unselected population. Oncodev Biol Med 1980;1: 191-8.

40. Beaudonnet A, Gounon G, Pichot J, Revenant MC. Sex- and agerelated influences on carcinoembryonic antigen in blood. Clin Chem 1981;27:771.

41. van Nagell JR Jr, Donaldson ES, Hanson MB, Gay EC, Pavlik EJ. Biochemical markers in the plasma and tumors of patients with gynecologic malignancies. Cancer 1981;48(2 Suppl):495-503.

42. Goldenberg DM, Neville AM, Carter AC, Go VL, Holyoke ED, Isselbacher $\mathrm{KJ}$, et al. CEA (carcinoembryonic antigen): its role as a marker in the management of cancer. J Cancer Res Clin Oncol 1981;101:239-42.

43. Booth SN, Jamieson GC, King JP, Leonard J, Oates GD, Dykes $\mathrm{PW}$. Carcinoembryonic antigen in management of colorectal carcinoma. Br Med J 1974;4:183-7.

44. Arnaud JP, Koehl C, Adloff M. Carcinoembryonic antigen (CEA) in diagnosis and prognosis of colorectal carcinoma. Dis Colon Rectum 1980;23:141-4.

45. Szymendera JJ, Nowacki MP, Szawłowski AW, Kamińska JA. Predictive value of plasma CEA levels: preoperative prognosis and postoperative monitoring of patients with colorectal carcinoma. Dis Colon Rectum 1982;25:46-52.

46. Wanebo HJ, Rao B, Pinsky CM, Hoffman RG, Stearns M, Schwartz MK, et al. Preoperative carcinoembryonic antigen level as a prognostic indicator in colorectal cancer. N Engl J Med 1978; 299:448-51.

47. Armitage NC, Davidson A, Tsikos D, Wood CB. A study of the reliability of carcinoembryonic antigen blood levels in following the course of colorectal cancer. Clin Oncol 1984;10:141-7.

48. Midiri G, Amanti C, Benedetti M, Campisi C, Santeusanio G, Castagna $\mathrm{G}$, et al. CEA tissue staining in colorectal cancer patients. A way to improve the usefulness of serial serum CEA evaluation. Cancer 1985;55:2624-9.

49. Duffy MJ. Carcinoembryonic antigen as a marker for colorectal cancer: is it clinically useful? Clin Chem 2001;47:624-30.

50. Reiter W, Stieber P, Reuter C, Nagel D, Lau-Werner U, Lamerz R. Multivariate analysis of the prognostic value of CEA and CA 19-9 serum levels in colorectal cancer. Anticancer Res 2000;20(6D): 5195-8.

51. Diez M, Pollan M, Müguerza JM, Gaspar MJ, Duce AM, Alvarez MJ, et al. Time-dependency of the prognostic effect of carcinoembryonic antigen and p53 protein in colorectal adenocarcinoma. Cancer 2000;88:35-41.

52. Nissan A, Stojadinovic A, Shia J, Hoos A, Guillem JG, Klimstra D, et al. Predictors of recurrence in patients with T2 and early T3, N0 adenocarcinoma of the rectum treated by surgery alone. J Clin Oncol 2006;24:4078-84.

53. Takagawa R, Fujii S, Ohta M, Nagano Y, Kunisaki C, Yamagishi S, et al. Preoperative serum carcinoembryonic antigen level as a predictive factor of recurrence after curative resection of colorectal cancer. Ann Surg Oncol 2008;15:3433-9.
54. Kanellos I, Zacharakis E, Kanellos D, Pramateftakis MG, Tsahalis T, Altsitsiadis E, et al. Prognostic significance of CEA levels and detection of CEA mRNA in draining venous blood in patients with colorectal cancer. J Surg Oncol 2006;94:3-8.

55. Lin JK, Lin CC, Yang SH, Wang HS, Jiang JK, Lan YT, et al. Early postoperative CEA level is a better prognostic indicator than is preoperative CEA level in predicting prognosis of patients with curable colorectal cancer. Int J Colorectal Dis 2011;26:1135-41.

56. Lee WS, Baek JH, Kim KK, Park YH. The prognostic significant of percentage drop in serum CEA post curative resection for colon cancer. Surg Oncol 2012;21:45-51.

57. Oussoultzoglou E, Rosso E, Fuchshuber P, Stefanescu V, Diop B, Giraudo G, et al. Perioperative carcinoembryonic antigen measurements to predict curability after liver resection for colorectal metastases: a prospective study. Arch Surg 2008;143:1150-8.

58. Suarez J, Vera R, Balen E, Gomez M, Arias F, Lera JM, et al. Pathologic response assessed by Mandard grade is a better prognostic factor than down staging for disease-free survival after preoperative radiochemotherapy for advanced rectal cancer. Colorectal Dis 2008;10:563-8.

59. Park YA, Sohn SK, Seong J, Baik SH, Lee KY, Kim NK, et al. Serum CEA as a predictor for the response to preoperative chemoradiation in rectal cancer. J Surg Oncol 2006;93:145-50.

60. Perez RO, São Julião GP, Habr-Gama A, Kiss D, Proscurshim I, Campos FG, et al. The role of carcinoembriogenic antigen in predicting response and survival to neoadjuvant chemoradiotherapy for distal rectal cancer. Dis Colon Rectum 2009;52:1137-43.

61. 1997 update of recommendations for the use of tumor markers in breast and colorectal cancer. Adopted on November 7, 1997 by the American Society of Clinical Oncology. J Clin Oncol 1998;16: 793-5.

62. Meyerhardt JA, Mangu PB, Flynn PJ, Korde L, Loprinzi CL, Minsky BD, et al. Follow-up care, surveillance protocol, and secondary prevention measures for survivors of colorectal cancer: American Society of Clinical Oncology clinical practice guideline endorsement. J Clin Oncol 2013;31:4465-70.

63. National Institute of Clinical Excellence (NICE). Colorectal cancer: diagnosis and management [Internet]. London: National Institute of Clinical Excellence; 2011 [2018 Nov 1]. Available from: https://www.nice.org.uk/guidance/cg131.

64. Yamamoto M, Maehara Y, Sakaguchi Y, Mine H, Yamanaka T, Korenaga $\mathrm{D}$, et al. Distributions in CEA doubling time differ in patients with recurrent colorectal carcinomas. Hepatogastroenterology 2004;51:147-51.

65. Wood CB, Ratcliffe JG, Burt RW, Malcolm AJ, Blumgart LH. The clinical significance of the pattern of elevated serum carcinoembryonic antigen (CEA) levels in recurrent colorectal cancer. $\mathrm{Br} J$ Surg 1980;67:46-8.

66. The Royal College of Phycisians; The The Royal College of Radiologists. Evidence-based Indications for the use of PET-CT in the UK 2013. London; Royal College of Phycisians; 2013.

67. Fletcher JW, Djulbegovic B, Soares HP, Siegel BA, Lowe VJ, Ly- 
man GH, et al. Recommendations on the use of 18F-FDG PET in oncology. J Nucl Med 2008;49:480-508.

68. Stelzner S, Hellmich G, Koch R, Ludwig K. Factors predicting survival in stage IV colorectal carcinoma patients after palliative treatment: a multivariate analysis. J Surg Oncol 2005;89:211-7.

69. Sun LC, Chu KS, Cheng SC, Lu CY, Kuo CH, Hsieh JS, et al. Preoperative serum carcinoembryonic antigen, albumin and age are supplementary to UICC staging systems in predicting survival for colorectal cancer patients undergoing surgical treatment. BMC Cancer 2009;9:288.

70. Thirunavukarasu P, Talati C, Munjal S, Attwood K, Edge SB,
Francescutti V. Effect of Incorporation of pretreatment serum carcinoembryonic antigen levels into AJCC staging for colon cancer on 5-year survival. JAMA Surg 2015;150:747.

71. Kim CG, Ahn JB, Jung M, Beom SH, Heo SJ, Kim JH, et al. Preoperative serum carcinoembryonic antigen level as a prognostic factor for recurrence and survival after curative resection followed by adjuvant chemotherapy in stage III colon cancer. Ann Surg Oncol 2017;24:227-35.

72. Makela JT, Laitinen SO, Kairaluoma MI. Five-year follow-up after radical surgery for colorectal cancer. Results of a prospective randomized trial. Arch Surg. 1995;130:1062-7. 